\title{
ANALISIS EFISIENSI DAN EFEKTIFITAS KREDIT UNTUK MENINGKATKAN KINERJA KEUANGAN PADA PD.BANK DAERAH LAMONGAN
}

\author{
*)Haris Bashori \\ Fakultas Ekonomi \\ Universitas Islam Lamongan
}

\begin{abstract}
ABSTRAK
Resiko kredit merupakan salah satu faktor yang mendapatkan perhatian bagi PD. Bank Daerah Lamongan, hal ini dikarenakan resiko NPL akan mempengaruhi Bank dalam menyalurkan kredit. Sebagaimana halnya dalam analisis laporan keuangan untuk menyajikan indikator-indikator yang penting dari keadaan keuangan dan melihat kinerja keuangan perbankan itu sendiri. Tujuan dari penelitian ini adalah untuk mengetahui pemberian kreditnya sudah efisien dan efektif apa belum dalam peningkatan kinerja keuangan PD.BPR Bank Daerah Lamongan. Hasil menunjukkan bahwa kinerja keuangan PD.Bank Daerah Lamongan dalam kondisi stabil (dari rasio likuiditas, solvabilitas, dan rentabilitas). Sebab terjadi kenaikan pada beberapa tahun. Sedangkan perhitungan mengenai efisien dan efektivitas kredit dari LDR dan NPL masing-masing rasio dalam kondisi aman menurut aturan Bank Indonesia. Dimana nilai LDR masih kurang dari kisaran $80 \%$ sampai $110 \%$ sedangkan nilai NPL masih dalam kisaran dibawah 5 atau masih dalam taraf aman.
\end{abstract}

Kata kunci : Efisisensi, Efektivitas dan Kinerja Keuangan.

\section{LATAR BELAKANG}

Pemberian kredit yang tidak memperhatikan kebijakan dan prosedur yang ada akan mengundang timbulnya penyimpangan-penyimpangan yang lain. Salah satu hal yang paling penting dalam pemberian kredit dengan melakukan deteksi dini ( keefektifitas/evaluasi kembali) atas kredit yang diduga bermasalah. Sehingga kredit tersebut dapat diselamatkan dan terhindar dari kemacetan. Untuk menghindari rasio kredit yang tinggi dari penyaluran kredit yang tidak efisien, sehingga perlu dipertimbangkan alokasi dana yang tinggi. Untuk mendukung pemberian kredit yang efektif, pilihan bank juga membutuhkan adanya informasi, yaitu informasi yang dianggap obyektif dan tidak direkayasa. Salah satu cara yang dilakukan untuk memperoleh informasi tersebut adalah melalui pelaksanaan serangkaian kegiatan pemeriksaan. Pemeriksaan tersebut meliputi pemeriksaan keuangan dan pemeriksaan operasional. Pemeriksaan keuangan merupakan pemeriksaan terhadap kondisi dan posisi keuangan. Sedangkan operasional merupakan penilaian efisiensi dan efektivitas atas metode dan prosedur operasi dalam suatu perusahaan.

\section{RUMUSAN MASALAH}

1. Bagaimana tingkat efiensi dan efektivitas kredit pada PD.Bank Daerah Lamongan? 
2. Bagaimana kinerja keuangan yang diukur dari likiuditas, rentabilitas dan solvabilitas PD.Bank Daerah Lamongan ?

\section{METODE}

Menggunakan analisa horizontal yaitu membandingkan laporan keuangan selama 3 tahun untuk mengetahui perubahanperubahan yang terjadi. Analisa kinerja keuangan perusahaan menggunakan rasio likuiditas, rasi solvabilitas, rasio rentabilitas dan efektivitas derta efisiensi menggunakan Loan to Deposit Ratio (LDR) dan Non Perfoming Loans (NPL).

\section{HASIL DAN PEMBAHASAN}

a. Rasio likuiditas

Mengukur kemampuan bank dalam memenuhi kewajibannya terhadap para deposan dengan harta yang paling liquid yang dimiliki oleh bank

PERHITUNGAN

RASIO

LIKUIDITAS

\begin{tabular}{|l|l|l|l|}
\hline $\begin{array}{l}\text { Rasio } \\
\text { Keuangan }\end{array}$ & $\begin{array}{l}\mathbf{2 0 1 1} \\
(\%)\end{array}$ & $\begin{array}{l}\mathbf{2 0 1 2} \\
(\mathbf{\%})\end{array}$ & $\begin{array}{l}\mathbf{2 0 1 3} \\
(\mathbf{\%})\end{array}$ \\
\hline $\begin{array}{l}\text { Quick } \\
\text { ratio }\end{array}$ & 74,43 & 63,35 & 85,05 \\
\hline $\begin{array}{l}\text { Asset to } \\
\text { loans ratio }\end{array}$ & 79,89 & 96,92 & 81,79 \\
\hline
\end{tabular}

Dari perhitungan diatas dapat dijelaskan nilai rasio likuiditas apabila dilihat dari quick ratio tahun 2012 mengalami penurunan yang tidak significant,dan kembali meningkat di tahun 2013, hal ini menunjukkan selama 3 tahun tersebut mencerminkan pebandingan aktiva lancar PD.BANK DAERAH
LAMONGAN dengan total deposito yang cukup stabil.

Pada perhitungan asset to loans ratio memberikan gambaran yang serupa, namun justru di tahun 2013 mengalami penurunan, hal tersebut dikarenakan total kewajiban di tahun 2012 sangat tinggi namun tidak diimbangi dengan kenaikan total aktiva.

b. Rasio solvabilitas

Mengukur kemampuan bank mencari sumber dana untuk melihat efisiensi bagi pihak manajemen bank tersebut.

PERHITUNGAN

RASIO SOLVABILITAS

\begin{tabular}{|l|l|l|l|}
\hline $\begin{array}{l}\text { Rasio } \\
\text { Keuangan }\end{array}$ & $\begin{array}{l}\mathbf{2 0 1 1} \\
(\boldsymbol{\%})\end{array}$ & $\begin{array}{l}\mathbf{2 0 1 2} \\
(\mathbf{\%})\end{array}$ & $\begin{array}{l}\mathbf{2 0 1 3} \\
(\boldsymbol{\%})\end{array}$ \\
\hline $\begin{array}{l}\text { Primary } \\
\text { ratio }\end{array}$ & 3,87 & 4,42 & 5,23 \\
\hline $\begin{array}{l}\text { Risk asset } \\
\text { ratio }\end{array}$ & 4,86 & 5,91 & 6,70 \\
\hline
\end{tabular}

Dari perhitungan data diatas dari primary ratio yaitu melihat perbandingan antara odal dan total asset terus mengalami peningkatan selama 3 periode. Hal ini menunjukkan bahwa peningkatan modal seimbang dengan peningkatan asset PD.Bank Daerah Lamongan. Sehingga nasabah akan merasa nyaman menginvestasikan dananya.

Pada risk asset ratio juga mengalami peningkatan yang relatif significant. Nilai risk asset ratio ini menunjukkan bahwa perbandingan modal dengan total aktiva setelah dikurangi cash asset 
tetap mengalami peningkatan selama 3 tahun tersebut.

c. Rasio rentabilitas

Mengukur tingkat efisiensi usaha dan profitabilitas yang dicapai oleh bank yang bersangkutan.

PERHITUNGAN

RATIO

RENTABILITAS

\begin{tabular}{|l|l|l|l|}
\hline $\begin{array}{l}\text { Rasio } \\
\text { Keuangan }\end{array}$ & $\begin{array}{l}\mathbf{2 0 1 1} \\
(\boldsymbol{\%})\end{array}$ & $\begin{array}{l}\mathbf{2 0 1 2} \\
(\boldsymbol{\%})\end{array}$ & $\begin{array}{l}\mathbf{2 0 1 3} \\
(\boldsymbol{\%})\end{array}$ \\
\hline NPM & 68,57 & 67,08 & 77,66 \\
\hline ROA & 1,59 & 2,37 & 2,30 \\
\hline
\end{tabular}

Hasil perhitungan menunjukkan nilai NPM mengalami penurunan di tahun 2013 meskipun kecil, namun di tahun 2012 mengalami peningkatan yang significant. Hal ini menunjukkan perbandingan antara net income dengan operating income di tahun 2013 sempat mengalami penurunan. Kondisi ini bermakna bahwa semakin besar nilai NPM maka kinerja perusahaan akan semakin produktif sehingga akan meningkatkan kepercayaan nasabah terhadap banknya.

Apabila dilihat dari return on asset (ROA), peningkatan yang cukup sicnificant terjadi pada tahun 2012, namun mengalami penurunan di tahun 2012 meskipum kecil.

d. Loan to deposit Ratio

Mengukur komposisi jumlah kredit yang diberikan dibandingkan dengan jumlah dana masyarakat dan modal sendiri yang digunakan.
PERHITUNGAN LOAN TO DEPOSIT RATIO

\begin{tabular}{|l|l|l|l|}
\hline $\begin{array}{l}\text { Rasio } \\
\text { Keuangan }\end{array}$ & $\begin{array}{l}\mathbf{2 0 1 1} \\
(\boldsymbol{\%})\end{array}$ & $\begin{array}{l}\mathbf{2 0 1 2} \\
(\boldsymbol{\%})\end{array}$ & $\begin{array}{l}\mathbf{2 0 1 3} \\
(\boldsymbol{\%})\end{array}$ \\
\hline LDR & 84,18 & 81,79 & 94,99 \\
\hline
\end{tabular}

Perhitungan diatas menunjukkan bahwa PD.Bank Daerah Lamongan sudah memenuhi batas aman dari peraturan pemerintah yaitu besar LDR antar $80 \%$ sampai $110 \%$, maka semakin banyak jumlah kredit yang diberikan semakin tinggi pula LDR, dan begitu sebaliknya. Adanya kegiatan ini juga akan berpengaruh pada tingkat bunga yang diperoleh bank, karena dalam pemberian kredit akan ditetapkan sejumlah bunga yang akan menjadi pendapatan bagi bank. Apabila dilihat keseluruhan, besar kecilnya pemberian kredit akan berpengaruh terhadap nilai Loan to deposit ratio karena salah satu indikator dalam perhitungannya adalah jumlah kredit yang diberikan.

e. Non performing Loan

Mengukur besarnya jumlah kredit bermasalah pada suatu bank dibanding dengan total keseluruhan kreditnya.

PERHITUNGAN NON PERFORMING LOAN

\begin{tabular}{|l|l|l|l|}
\hline $\begin{array}{l}\text { Rasio } \\
\text { Keuangan }\end{array}$ & $\begin{array}{l}\mathbf{2 0 1 1} \\
(\boldsymbol{\%})\end{array}$ & $\begin{array}{l}\mathbf{2 0 1 2} \\
(\boldsymbol{\%})\end{array}$ & $\begin{array}{l}\mathbf{2 0 1 3} \\
(\boldsymbol{\%})\end{array}$ \\
\hline NPL & 3,08 & 2,45 & 1,98 \\
\hline
\end{tabular}

Dari perhitungan diatas nilai Non Performing Loan (NPL) PD Bank Daerah Lamongan tahun 2011- 
2013 masih dibawa $5 \%$. Hal ini berdasarkan peraturan pemerintah jumlah kredit bermasalah masih dalam taraf stabil karena dibawah 5 $\%$. Utuk mempertahankan agar nilai NPL dibawah $5 \%$, maka penerapan strategi pemberian kredit harus efektif dan afisien.

\section{KESIMPULAN}

1. Apabila dilihat dri perhitungan Loan to Deposit Ratio (LDR ) dan Non Performing Loan (NPL) masing-masing ratio dalam perhitungan atau kondisi aman sesuai dengan aturan Bank Indonesia. Dimana nilai LDR masih dalam kisaran $80 \%$ sampai $110 \%$ dan nilai NPL masih dalam kisaran sibawah $5 \%$. Hal ini menunjukkan bahwa pemberian kredit yang dilakukan PD.Bank Daerah Lamongan masih dalam kondisi efektif dan efisien.

2. Apabila dilihat dari kinerja keuangan 3 tahun terakhir kinerja keuangan PD.Bank daerah Lamongan dalam kondisi stabil. Meskipun terjadi penurunan namun sangat tipis dan bisa kembali naik.

\section{SARAN}

PD.Bank Daerah Lamongan perlu meningkatkan sistem, strategi, tata cara pemberian kredit terhadap nasabahnya, sehingga tingkat keamanan dan kesehatan bank tetap terjaga. Sebaliknya nilai NPL dan LDR lebih ditingkatkan lagi dengan cara memperhatikan faktor-faktor yang mempengaruhi. Misalnya : dana pihak ketiga, jumlah kredit yang diberikan.

\section{DAFTAR PUSTAKA}

Basu Swasta dan T.hani Handoko, 2000, Manajemen Pemasaran dan Analisis Perilaku Konsumen, edisi 1, Liberty : Jakarta

Philip Kotler dan Gary Armstrong, 2001, Prinsip-Prinsip Pemasaran, edisi kedelapan, Erlangga : jakarta

Rusdian, 1999, Manajemen Perilaku, Salemba Empat : Jakarta.

Arikunto Suharsimi, 1998, Prosedur Penelitian, Cetakan 14, PT.Rieneka Cipta : Jakarta
Ristiyanti Prasetijo dan John J.O.I Ihalauw, 2005, Perilaku Konsumen, Andi : Yogyakarta

Sumardi, Suryabrata dkk, 2003, Metodologi Penelitian, Yogyakarta : Raja Grafindo Persada

www.ilmuekonomi.go.id 